\title{
Hormonal control of salt and water balance in vertebrates
}

\author{
Stephen D. McCormick ${ }^{\mathrm{a}, \mathrm{b}, *}$, Don Bradshaw ${ }^{\mathrm{c}}$ \\ ${ }^{a}$ USGS, Conte Anadromous Fish Research Center, Turners Falls, MA, USA \\ ${ }^{\mathrm{b}}$ Organismic and Evolutionary Biology Program, University of Massachusetts, Amherst, MA, USA \\ ${ }^{\mathrm{c}}$ School of Animal Biology, The University of Western Australia, Perth, WA 6009, Australia
}

Received 23 August 2005; revised 3 December 2005; accepted 13 December 2005

\begin{abstract}
The endocrine system mediates many of the physiological responses to the homeostatic and acclimation demands of salt and water transport. Many of the hormones involved in the control of salt and water transport are common to all vertebrates, although their precise function and target tissues have changed during evolution. Arginine vasopressin (vasotocin), angiotensin II, natriuretic peptides, vasoactive intestinal peptide, urotensin II, insulin and non-genomic actions of corticosteroids are involved in acute (minutes and hours) alterations in ion and water transport. This rapid alteration in transport is primarily the result changes in behavior, blood flow to osmoregulatory organs, and membrane insertion or activation (e.g., phosphorylation) of existing transport proteins, ion and water channels, contransporters and pumps. Corticosteroids (through genomic actions), prolactin, growth hormone, and insulin-like growth factor I primarily control long-term (several hours to days) changes in transport capacity that are the result of synthesis of new transport proteins, cell proliferation, and differentiation. In addition to the important task of establishing broad evolutionary patterns in hormones involved in ion regulation, comparative endocrinology can determine species and population level differences in signaling pathways that may be critical for adaptation to extreme or rapidly changing environments.
\end{abstract}

(C) 2006 Published by Elsevier Inc.

Keywords: Osmoregulation; Vertebrates; Ion transport; AVP; AVT; ANP; Angiotensin; Aldosterone; Cortisol; Growth hormone; Prolactin; IGF-I

\section{Physiological requirements for salt and water transport}

Maintenance of constant intracellular and extracellular ionic and osmotic environment (Bernard's constancy of 'le milieu intérieur') is critical for the normal functioning of cells. With several notable exceptions, such as hagfish, sharks and ureotelic marine frogs, the majority of vertebrates maintain a remarkably similar salt content of their extracellular fluid, approximately one-third that of seawater. This basic strategy results in different transport demands for vertebrates depending on their external environment. In fresh water environments vertebrates must actively take up salts, whereas in seawater they must secrete excess salts. In terrestrial environments vertebrates must

\footnotetext{
${ }^{*}$ Corresponding author. Fax: +1 4138639810.

E-mail address: mccormick@umext.umass.edu (S.D. McCormick).
}

conserve water. The demands for ion and water transport can vary greatly, depending on both internal factors such as metabolic rate, and external factors such as salinity or water availability.

Hormones play a critical role in signaling and controlling the homeostatic and acclimation demands of salt and water transport (Bentley, 1998). In spite of the differences in transport needs and capabilities among vertebrates (and even the organs responsible for ion transport) many of the hormones involved are remarkably similar. In addition to acting on the basic mechanisms of ion transport, natural selection will act on the underlying neuroendocrine controls. Our understanding of large evolutionary trends (e.g., evolution of terrestriality) and adaptation of species to new or severe environments requires knowledge of the underlying control mechanisms for salt and water regulation. The purpose of this overview is to provide a general framework for the hormonal control of osmoregulation in vertebrates 
54 and to highlight the contributed papers to a symposium on 55 "Hormonal Control of Water and Salt Balance in Verte56 brates" held in Boston in May 2005 as part of the Fifteenth 57 International Congress of Comparative Endocrinology.

\section{Acute endocrine responses}

Most organisms have at least a limited capacity to respond to an osmotic or ionic challenge by rapidly changing existing transport mechanism. Some of these may be independent of hormones (autoregulatory), such as changes in ion availability to transporters. Most changes in ion transport, however, are cued by neuroendocrine or endocrine factors. Although there is a continuum of temporal responses, we can roughly divide transport responses into those that activate existing transport mechanisms (acute regulatory response), and those that require development of new proteins and cells (acclimation response) (Fig. 1). A

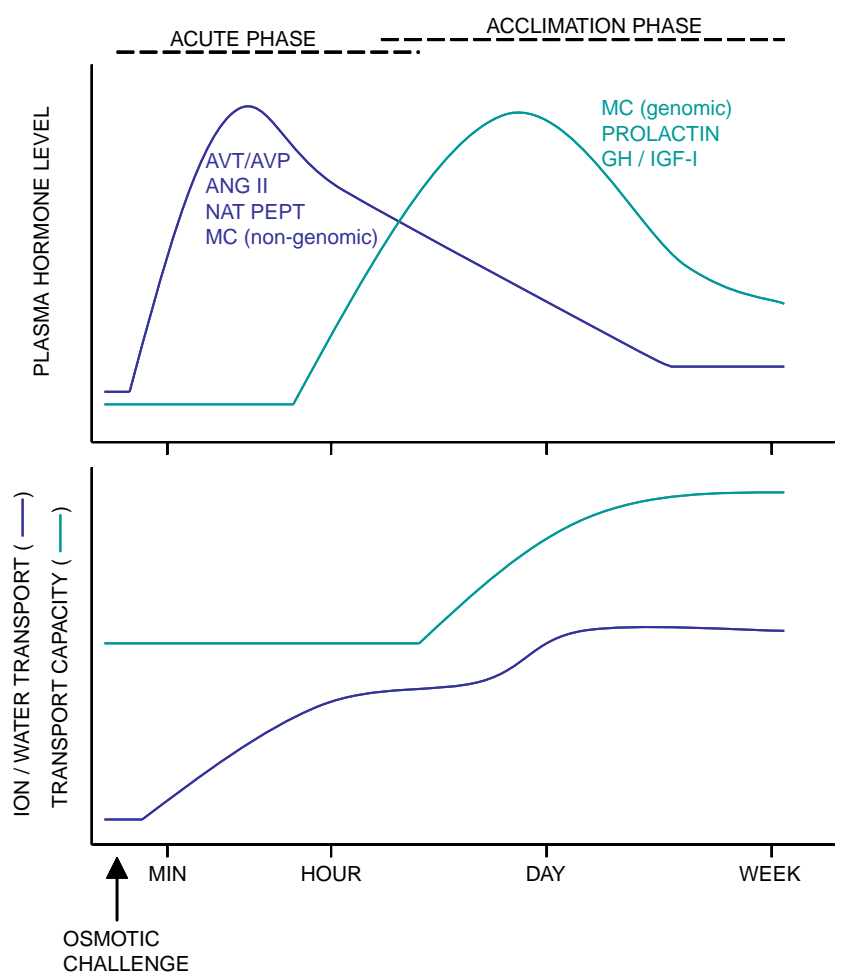

Fig. 1. Schematic diagram of the hormonal control of ion and water transport. Osmotic stimulus (such as alteration in internal osmotic pressure caused by dehydration or exposure to seawater) results in release of rapid acting hormones (blue) that activate existing proteins and cells to increase ion and/or water transport in the acute phase (seconds to hours) through stimulation of existing mechanism (e.g., insertion of aquaporins into membranes or phosphorylation of transporters). Osmotic stimuli and rapid acting hormones will increase long term acting hormones (green) to bring about increased protein synthesis, cell proliferation, differentiation and tissue reorganization that will allow increased transport capacity in the acclimation phase (several hours to several days). The ability to increase maximum transport capacity will be present only in species with phenotypic plasticity in response to osmotic challenge. Abbreviations: AVT $=$ arginine vasotocin; $\mathrm{AVP}=$ arginine vasopressin; $\mathrm{ANG} \mathrm{II}=$ angiotensin $\mathrm{II}$; NAT $\mathrm{PEPT}=$ natriuretic peptide $\mathrm{MC}=$ mineralocorticoid; $\mathrm{GH}=$ growth hormone; IGF-I = insulin-like growth factor I. classic example of an acute regulatory response is signaling by arginine vasotocin (AVT; or arginine vasopressin, AVP in the case of mammals) to induce antidiuresis and thus conserve water. Increased plasma osmolality (such as might occur following reduced water intake or exposure to seawater) signals osmosensors in the hypothalamus to release AVT. Increased circulating AVT binds to membrane $\mathrm{V}_{2}$-type AVT receptors in the renal collecting duct, resulting in the insertion of stored aquaporin (water channel) proteins into the plasma membrane. This increases water reabsorption by the kidney permitting restoration of plasma osmolality.

Although it is likely that the AVT/AVP hormone has an osmoregulatory role in most vertebrates, the AVT-aquaporin response may have evolved with terrestriality, since it has only been found to date in amphibians (Uchiyama and Konno, this volume) birds (Goldstein, this volume) and mammals (Table 1). AVT functions as a physiological antidiuretic hormone in the few species of reptiles that have been studied to date and reduces glomerular filtration rate and urine flow by acting on both $\mathrm{V}_{1}$-type receptors in the afferent arteriole and $\mathrm{V}_{2}$-type receptors found in the thin intermediate segment and collecting ducts (Bradshaw and Bradshaw, 1996). $\mathrm{V}_{2}$-type AVT receptors have also been localized in the reptilian nephron (Bradshaw and Bradshaw, 2002). Shane et al. (2006, this volume) have shown that AVT can stimulate amiloride-sensitive $(\mathrm{ENaC})$ sodium reabsorption in the A6 Xenopus kidney cell line. Recent evidence summarized by Balment (2006, this volume) indicates that AVT is involved in salt secretion and/or water conservation necessary for seawater acclimation of teleost fish. Although a $\mathrm{V}_{2}$-type AVT receptor has yet to be described in fish, Perrott et al. (1993) have found that AVT can cause increased cAMP in the trout renal tubules, consistent with a $\mathrm{V}_{2}$-type AVT receptor action in mammals. AVT at very low doses is antidiuretic in fish (Balment et al., 1993), but AVT receptors are upregulated in sea water and localized in the gill leaflets, suggesting a direct action of this peptide on the gills (Avella et al., 1999; Guibbolini et al., 1989). Thus, AVT's role in water conservation may have arisen early in vertebrates. It should be noted, however, that a wide diversity of fishes has yet to be examined. In particular it will be of interest to determine if this response is present in teleosts that are restricted to fresh water where demands for water conservation may have placed little selection on development or maintenance of this capacity. Acher (2002) has suggested that "striking evolutionary stability" of AVT/AVP is the result of strong selection pressure on maintaining the osmoregulatory function of this hormone. In contrast, the urea-based isosmotic strategy of cartilaginous fishes has 'released' these fish from selective pressure allowing a greater diversity of structure of AVT-like peptides in this group of vertebrates.

The natriuretic peptides, as their name implies, have important, acute osmoregulatory actions in vertebrates. Since most vertebrates appear to have at least three forms of natruretic peptides, generalization of their function must 
Table 1

Overview of major physiological function and target tissues (parentheses) of hormones critical to ion and water balance in vertebrates

\begin{tabular}{|c|c|c|c|c|c|c|}
\hline & Elasmobranch & Teleost & Amphibian & Reptile & Bird & Mammal \\
\hline AVT/AVP & $\begin{array}{l}\text { Water retention } \\
\downarrow \text { GFR }\end{array}$ & $\begin{array}{l}\text { Salt secretion ? } \\
\uparrow \mathrm{Cl} \text { secretion: } \mathrm{G}\end{array}$ & $\begin{array}{l}\text { Water retention } \\
\uparrow \text { absorption: K,S,UB } \\
\downarrow \text { GFR }\end{array}$ & $\begin{array}{l}\text { Water retention } \\
\uparrow \text { tubular reabsorption } \\
\downarrow \text { GFR }\end{array}$ & $\begin{array}{l}\text { Water retention } \\
\uparrow \text { tubular reabsorption } \\
\downarrow \text { GFR }\end{array}$ & $\begin{array}{l}\text { Water retention } \\
\uparrow \text { tubular reabsorption }\end{array}$ \\
\hline Angiotensin II & $\begin{array}{l}\text { Water retention } \\
\uparrow \text { drinking } \\
\uparrow 1 \text { a-hydroxycort }\end{array}$ & $\begin{array}{l}\text { Water retention } \\
\uparrow \text { drinking } \\
\uparrow \text { cortisol }\end{array}$ & $\begin{array}{l}\text { Water retention } \\
\uparrow \text { absorption: } \mathrm{K} \\
\uparrow \text { aldosterone }\end{array}$ & $\begin{array}{l}\text { Water retention } \\
\uparrow \text { drinking } \\
\uparrow \text { aldosterone and cort }\end{array}$ & $\begin{array}{l}\text { Water retention } \\
\uparrow \text { drinking }\end{array}$ & $\begin{array}{l}\text { Water retention } \\
\uparrow \text { drinking } \\
\uparrow \text { aldosterone }\end{array}$ \\
\hline Natiuretic Pept & $\begin{array}{l}\text { Salt secretion } \\
\uparrow N \text { a secretion: } R G\end{array}$ & $\begin{array}{l}\text { Salt secretion } \\
\downarrow \text { drinking } \\
\downarrow \text { Na uptake:I }\end{array}$ & $\begin{array}{l}\text { Water and salt secretion } \\
\uparrow \text { GFR } \\
\downarrow \text { aldosterone }\end{array}$ & $?$ & $\begin{array}{l}\text { Water and salt secretion } \\
\uparrow \text { GFR } \\
\downarrow \text { aldosterone } \\
\uparrow N a \text { secretion:SG }\end{array}$ & $\begin{array}{l}\text { Water and salt secretion } \\
\uparrow \text { GFR } \\
\downarrow \text { aldosterone }\end{array}$ \\
\hline Corticosteroid & $\begin{array}{l}\text { Salt secretion? } \\
\uparrow N a \text { secretion: } R G\end{array}$ & $\begin{array}{l}\text { Salt secretion (? uptake) } \\
\uparrow N a \text { secretion: G } \\
\uparrow N a \text { and water uptake:I }\end{array}$ & $\begin{array}{l}\text { Salt retention } \\
\uparrow \mathrm{Na} \text { aborption: S,I,UB }\end{array}$ & $\begin{array}{l}\text { Salt retention } \\
\uparrow N a \text { reabsorption:K,I,UB }\end{array}$ & $\begin{array}{l}\text { Salt retention } \\
\uparrow \mathrm{Na} \text { reabsorption:K,I }\end{array}$ & $\begin{array}{l}\text { Salt retention } \\
\uparrow N \text { a reabsorption: } \\
\text { K,I,UB,SG,MG }\end{array}$ \\
\hline Prolactin & $?$ & $\begin{array}{l}\text { Salt and water retention } \\
\downarrow \mathrm{Na} \text { and water perm:G,I }\end{array}$ & $\begin{array}{l}\text { Salt and water retention } \\
\downarrow \mathrm{Na} \text { and water perm:S }\end{array}$ & & $\begin{array}{l}\text { "Milk" Production } \\
\uparrow \text { growth and secretion:CS }\end{array}$ & $\begin{array}{l}\text { Milk production } \\
\uparrow \text { growth and secretion:MG }\end{array}$ \\
\hline GH/IGF-I & $?$ & $\begin{array}{l}\text { Salt secretion } \\
\uparrow N a \text { secretion: G } \\
\uparrow \text { gill MR cells }\end{array}$ & $?$ & & $?$ & $\begin{array}{l}\text { Salt and water retention } \\
\uparrow \text { Kidney growth } \\
\uparrow \text { tubular Na reabsorption } \\
\downarrow \text { GFR }\end{array}$ \\
\hline VIP & $\begin{array}{l}\text { Salt secretion } \\
\uparrow N a \text { secretion:RG }\end{array}$ & $?$ & $?$ & $\begin{array}{l}\text { Salt secretion } \\
\uparrow \mathrm{Na} \text { secretion:SG }\end{array}$ & $\begin{array}{l}\text { Salt secretion } \\
\uparrow \mathrm{Na} \text { secretion:SG }\end{array}$ & $?$ \\
\hline
\end{tabular}

$\mathrm{K}=$ kidney, $\mathrm{I}=$ intestine, $\mathrm{UB}=$ urinary bladder, $\mathrm{S}=$ skin, $\mathrm{SG}=$ sweat gland, $\mathrm{MG}=$ mammary gland; Ad=adrenal/interrenal; $\mathrm{RG}=\mathrm{rectal}$ gland; $\mathrm{MR}$-mitochondrion-rich; $\mathrm{CS}=$ crop sac; $\mathrm{GFR}=$ glomerular filtration rate. Indication of physiological effect of a hormone indicates that it is present in at least one species, but may not be present in all. See Bentley (1998) and text for references. * increased aldosterone in response to ANP has been found in turkeys (see Toop and Donald, 2004). 
be done with some caution (Takei, 2001; Toop and Donald, 2004). It appears that natriuretic peptides in mammals primarily function to control blood volume. Donald and Trajanovska (2006, this volume) suggest that in amphibians, natriuretic peptides function primarily to protect the animal from hypervolemia following periods of rapid rehydration. This effect is caused primarily by direct effects on GFR and indirect effects on corticosteroid secretion. In contrast, Tsukada and Takei (2006, this volume) provide evidence that natriuretic peptides (specifically atrial natriuretic peptide, ANP) have a primary role in ion regulation in eels (and perhaps in many teleosts), and are only secondarily involved in volume regulation. They demonstrate that ANP inhibits both drinking behavior in seawater (thereby limiting salt uptake) and intestinal absorption of $\mathrm{Na}^{+}$.

In addition the rapid actions that can be brought about by insertion of existing proteins into membranes and control of blood flow to osmoregulatory organs, hormonally induced changes in behavior can have important osmoregulatory effects. ANG II has widespread effects on drinking behavior among vertebrates, thus promoting water uptake (Table 1; Nishimura, 1987). An interesting exception is in adult amphibians where angiontensis II does not promote drinking (these animals apparently do not drink) but does promote behavioral water uptake by increasing the water absorption response, wherein the animals press a highly vascularized ventral skin patch into water or moist soil (Uchyama and Konno, this volume). Following the discovery of an unusual form of angiontensin II in elasmobranchs (Takei et al., 1993), it has been found that angiontensin has an important role in drinking behavior and steroidogenesis is these basal vertebrates (Anderson et al., 2006, this volume).

\section{Acclimation endocrine responses}

Acclimation responses increase the overall capacity of an organism to perform a physiological function. The acclimation response is similar or identical to phenotypic plasticity; its presence or absence will often determine the capacity of an animal to live in certain habitats and thus determine the ecological limits of species' distributions. A classic example of acclimation in human physiology is the increased capacity for oxygen extraction after exposure to high altitudes. This occurs over a period of days to weeks and is the result of changes in hemoglobin content, number of red blood cells, capillary growth, and lung capacity.

In teleost fish the acclimation responses of the gill, gut and kidney are largely responsible for the capacity of teleost fish to move between fresh water and seawater, termed euryhalinity. In the gill one of the primary seawater acclimation responses is an increase in the number and size of salt secretory cells, termed "chloride cells" or "mitochondrion-rich cells." These cells have high levels of $\mathrm{Na}^{+} / \mathrm{K}^{+}$ATPase, $\mathrm{Na}^{+}, \mathrm{K}^{+}, 2 \mathrm{Cl}^{-}$contransporter (NKCC) and the CFTR apical chloride channel that are responsible for salt secretion by chloride cells. In most teleost fish these trans- porters increase over 1-14 days following exposure to seawater (Hiroi et al., 2005; McCormick, 2001), thereby increasing the overall capacity of the tissue to secrete sodium and chloride. Cortisol upregulates these transporters in most euryhaline teleosts, and in several model euryhaline species there is an important interaction of cortisol with the growth hormone/insulin-like growth factor I axis to increase salt secretory capacity of the gill Sakamoto and McCormick (2006, this volume). Prolactin plays a critical role in acclimation of teleosts to fresh water, and acts antagonistically to the action of GH to promote seawater tolerance. Although the function of cortisol in ion regulation has been primarily ascribed to regulating salt secretory mechanisms, there is some evidence that cortisol also has a role in maintaining transport proteins that are important for ion uptake, including $\mathrm{Na}^{+} / \mathrm{K}^{+}$-ATPase (McCormick, 2001).

In most terrestrial vertebrates aldosterone has a critical role in regulating the long-term capacity for $\mathrm{Na}$ retention, primarily through increased synthesis of renal, urinary bladder and skin transport proteins. Laverty et al. (2006, this volume) review evidence for the role of aldosterone in mediating the increased $\mathrm{Na}^{+}$transport capacity of the avian lower intestine following acclimation to a low salt diet. This increased transport capacity is due to increased cell proliferation, tissue remodeling and increased expression of the epithelial $\mathrm{Na}^{+}$channel $(\mathrm{ENaC})$. Shane et al. (2006, this volume) have shown that the capacity of aldosterone to increase apical $\mathrm{ENaC}$ expression and sodium reabsorption is remarkably similar in kidney cell lines from amphibians and mammals. This classic genomic steroid action takes several hours, consistent with the synthesis of new proteins. There is also evidence for a more rapid, non-genomic action of aldosterone, though the membrane receptor and signal transduction for these rapid action are still unclear (Losel et al., 2002). Agamid lizards have been shown to respond slowly but effectively to changes in sodium status by a combination of renal and post-renal modifications of the urine (Bradshaw, 1997). There is some evidence that corticosterone may function to reduce renal sodium reabsorption in salt-loaded lizards, but aldosterone acts as a classical mineralocorticoid in the reptilian nephron, i.e., is natriferic and kaliuretic (Bradshaw and Rice, 1981).

It has long been held that in teleost fish cortisol carries out both glucocorticoid and mineralocorticoid function, as aldosterone is present only in very low concentrations in teleost fish. Aldosterone is present in primitive sarcopterygii (coelocanths and lungfish) (Bentley, 1998), and aldosterone may have evolved a mineralocorticoid function in conjunction with the evolutionary movement of these vertebrates to land. The recent findings that fish express a receptor with high sequence similarity with the mammalian mineralocorticoid receptor opens up the possibility of a more complex regulation of ion transport in teleost fish than previously appreciated Prunet et al. (2006, this volume). This receptor may be involved in osmoregulation, and if so cortisol might be working through two receptors 
to bring about both glucocorticoid and mineralocorticoid actions, or a 'missing' corticosteroid such as deoxycorticosterone may be acting through this putative mineralocorticoid receptor.

Pickford and Phillips (1959) were the first to demonstrate prolactin's important role in ion uptake in teleost fish. Prolactin exerts primarily long-term effects on membrane permeability and transport function of the gill, gut, and kidney (Hirano, 1986). Sakamoto and McCormick (2006) propose that cell proliferation and differentiation are important mechanisms through which prolactin exerts osmoregulatory actions in teleost fish. Prolactin also reduces salt and water permeability in the skin of urodele amphibians (Bentley, 1998). There is no apparent role of prolactin in the overall salt and water metabolism in birds and mammals, although this hormone has osmoregulatory action in the sense of promoting fluid production and secretion in the crop sac of some birds and mammary glands of mammals. It is tempting to speculate that this 'transfer of function' from whole animal osmoregulation to reproduction occurred in conjunction with the abandonment of freshwater during tetrapod evolution. With no selection pressure to maintain its fresh water osmoregulatory function, prolactin in terrestrial vertebrates may have been 'free' to adopt new functions. Since prolactin was already associated with the 'water drive' and fresh water spawning in amphibians, it may have been predisposed to adopt a reproductive function as tetrapods became wholly terrestrial.

As noted above, most teleosts upregulate gill chloride (mitochondrion-rich) cells and their associated transporters in response to environmental salinity, and that this acclimation response is controlled by cortisol and the GH/IGF-I axis. In an analogous fashion, the salt gland of many birds can increase in size and $\mathrm{Na}^{+}, \mathrm{K}^{+}$-ATPase content in response to environmental salinity (Skadhauge, 1981). These salinity-induced changes apparently require an intact hypophysio-adrenocortical axis, though the role of corticosteroids appears to be permissive. The size and $\mathrm{Na}^{+}$, $\mathrm{K}^{+}$-ATPase activity of the $\mathrm{NaCl}$ secreting rectal gland of euryhaline elasmobranchs also varies in response to environmental salinity (Piermarini and Evans, 2000; Pillans et al., 2005). It would be of interest to determine if GH and/ or IGF-I have a role in rectal and salt gland development and differentiation that accompanies salinity acclimation of elasmobranches and birds. To this end, preliminary studies indicate that GH treatment can increase the relative size of rectal gland in hammerhead sharks (Björnsson, Sundell and McCormick, unpublished results). GH and IGF-I have a clearly established role in repair of the kidney after tissue damage and the compensatory renal hypertrophy that occurs after hemilateral nephrectomy (Rabkin and Schaefer, 2004). In addition to these effects on growth and differentiation, IGF-I may directly and indirectly (through stimulation of renin release and inhibition of atrial natriuretic peptide) participate in glomerular and tubular sodium retention.

\section{Summary and perspectives}

In this review we have summarized the acute and acclimation endocrine responses that regulate physiological responses to osmotic challenges. Acute response are rapid (seconds to hours) that are the result of activation of existing transport mechanisms. Examples of acute regulation include behavioral changes such as drinking, altered blood flow, insertion of transporters into the plasma membrane, and phosphorylation of transporters. Acclimation responses occur over hours and days and are the result of synthesis of new transporters (hours), cells (days) or even tissue reorganization (several days to weeks). There is of course a continuum and overlap in the time course of these responses (Fig. 1) and the time course will differ among species. There are also examples of intermediate types of response, such as aldosterone's induction of the small G-protein, K-Ras2, that activates $\mathrm{ENaC}$ and increases renal sodium reabsorption within hours Uchiyama and Konnu (2006, this volume). While it is generally true that peptides have rapid actions and steroids and large protein hormones have longer-term actions, there are certainly exceptions; for example, aldosterone can have rapid, nongenomic action, and long-term remodeling can directly be controlled by peptides.

There are important interactions among endocrine systems that allow the coordination of ion transport processes within and among tissues and across acute and acclimation phases. Hormones that are activated in the acute phase are often important signals for release of hormones in the acclimation phase. For example, angiotensin II and naturetic peptides cause opposite effects on circulating levels of aldosterone, and this regulation appears to be shared among many vertebrates. The 'cross-talk' among hormones is clearly important in both fine-tuning and long-term adjustment of current transport and overall transport capacity.

We have emphasized the hormones that have a common osmoregulatory function among vertebrates (Table 1). There are other hormones that have important functions in ion and water balance that may be limited to a given phylum, or whose role in osmoregulation has only recently come under investigation. Insulin stimulates $\mathrm{ENaC}$-mediated $\mathrm{Na}^{+}$transport in kidney tubule cell lines from both Amphibia and mammals (Shane et al., 2006, this volume). Hughes et al. (2006, this volume) have found that melatonin increases the $\mathrm{Na}^{+}$secretion of the salt gland of saline-acclimated gulls, and that salt acclimation increases melatonin receptors in the salt gland. Catecholamines by virtue of their dramatic vasoactive actions can have impacts on renal and gill fluid homeostasis, and in teleost fish they also have direct effects on the function of chloride cells that are independent of their vascular effects (Marshall, 2003). Urotensin II, originally thought to be restricted to fish, in now known to be present in many vertebrates including mammals and may have widespread effects on fluid and ion homeostasis (Charrel et al., 2004). 
In outlining the broad evolutionary trends in hormone function (Table 1 and text), it is important to not that these represent the presence in a particular phylum, and that there are likely to be exceptions within any given phylum. Given the large number of species and diversity of habitats to which some phyla have become adapted, the absence (or addition) of a hormone function in some species or even whole clades is certainly possible. These may even be likely where a phyletic group represents an altered habitat or life history with fundamentally different osmotic challenges. The coevolution of hormones and their receptors is an intriguing area that comparative endocrinologists are uniquely positioned to investigate. As the major signaling pathway for environmental osmotic stress, it seems likely that the endocrine system will be a strong target of natural selection when animals are in osmotically extreme environments. This may result in differences in endocrine responses and control among closely related species, and even result in intraspecies (population level) differences. Understanding both broad evolutionary and microevolutionary patterns will help establish the how evolution has shaped the endocrine system and its control of osmoregulatory physiology.

\section{Uncited reference}

Goldstein (2006).

\section{References}

Acher, R., 2002. L'homéostase hydrique dans le vivant: organisation moléculaire, réflexes osmorégulateurs et évolution. Ann. Endocrinol. 63, 197-218.

Avella, M., Part, P., Ehrenfeld, J., 1999. Regulation of Cl- secretion in seawater fish (Dicentrarchus labrax) gill respiratory cells in primary culture. J. Physiol. (London) 516, 353-363.

Balment, R.J., Warne, J.M., Tierney, M., Hazon, N., 1993. Arginine vasotocin and fish osmoregulation. Fish Physiol. Biochem. 11, 1-6.

Balment, R.J., 2006. Gen. Comp. Endocrinol. (this volume).

Bentley, P.J., 1998. Comparative Vertebrate Endocrinology, third ed. Cambridge University Press, Cambridge.

Bradshaw, F.J., Bradshaw, S.D., 1996. Arginine vasotocin: Locus of action along the nephron of the Ornate Dragon Lizard, Ctenophorus ornatus. Gen. Comp. Endocrinol. 103, 281-289.

Bradshaw, S.D., 1997. Homeostasis in Desert Reptiles. Springer, Berlin and Heidelberg. 213 pp.

Bradshaw, S.D., Bradshaw, F.J., 2002. Mini-Review-Arginine Vasotocin: site and mode of action in the Reptilian kidney. Gen. Comp. Endocrinol. 126, 7-13.

Bradshaw, S.D., Rice, G.E., 1981. The effects of pituitary and adrenal hormones on renal and post-renal reabsorption of water and electrolytes in the lizard Varanus gouldii (Gray). Gen. Comp. Endocrinol. 44, 8293.

Charrel, N., Leprince, J., Dujardin, C., Tollemer, H., Barocini, M., Balment, R.J., Beauvillain, J.C., Vaudry, H., 2004. Biochemical characterisation and immunohistochemical localization of urotensin II in the human brainstem and spinal cord. J. Neurochem. 91, 110-118.

Donald, J.A., Trajanovska, S., 2006. A perspective on the role of natriuretic peptides in amphibian osmoregulation. Gen. Comp. Endocrinol. (this volume).

Goldstein, D.L., 2006. Regulation of the avian kidney by arginine vasotocin. Gen. Comp. Endocrinol. (this volume).
Guibbolini, M.E., Henderson, I.W., Mosley, W., Lahlou, B., 1989. Arginine vasotocin binding to isolated branchial cells of the eel: effect of salinity. J. Mol. Endocrinol. 1, 125-130.

Hirano, T., 1986. The spectrum of prolactin action in teleosts. In: Ralph, C.L. (Ed.), Comparative Endocrinology: Developments and Directions. A.R. Liss, New York, pp. 53-74.

Hiroi, J., McCormick, S.D., Ohtani-Kaneko, R., Kaneko, T., 2005. Functional classification of mitochondrion-rich cells in euryhaline Mozambique tilapia (Oreochromis mossambicus) embryos, by means of triple immunoflourescence staining for $\mathrm{Na}^{+} / \mathrm{K}^{+}$-ATPase, $\mathrm{Na}^{+} / \mathrm{K}^{+} / 2 \mathrm{Cl}^{-}$contransporter and CFTR anion channel. J. Exp. Biol. 208, 2023-2036.

Hughes, M.R., Kitamura, N., Poon, A.M.S., 2006. Osmoregulatory roles of melatonin in birds with salt glands. Gen. Comp. Endocrinol. (this volume).

Laverty, G., Elbrond, V.S., Aranason, S.S., Skadhauge, E., 2006. Endocrine regulation of ion transport in the avian lower intestine. Gen. Comp. Endocrinol. (this volume).

Losel, R., Feuring, M., Wehling, M., 2002. Non-genomic aldosterone action: from the cell membrane to human physiology. J. Steroid Biochem. Mol. Biol. 83, 167-171.

Marshall, W.S., 2003. Rapid regulation of $\mathrm{NaCl}$ secretion by estuarine teleost fish: coping strategies for short-duration freshwater exposures. Biochim. Biophys. Acta-Biomembranes 1618, 95-105.

McCormick, S.D., 2001. Endocrine control of osmoregulation in teleost fish. Am. Zool. 41, 781-794.

Nishimura, H., 1987. Role of the renin-angiotensin system in osmoregulation. In: Pang, P.K.T., Schreibman, M.P., Sawyer, W.H. (Eds.), Vertebrate Endocrinology: Fundamentals and Biomedical Implications, vol. 2. Academic Press, New York, pp. 157-187.

Perrott, MN., Sainsbury, R.J., Balment, R.J., 1993. Peptide hormone-stimulated second messenger production in the teleostean nephron. Gen. Comp. Endocrinol. 89, 387-395.

Pickford, G.E., Phillips, J.G., 1959. Prolactin, a factor promoting survival of hypophysectomized killifish in freshwater. Science 130, 454-455.

Piermarini, P.M., Evans, D.H., 2000. Effects of environmental salinity on $\mathrm{Na}^{+} / \mathrm{K}^{+}$-ATPase in the gills and rectal gland of a euryhaline elasmobranch (Dasyatis sabina). J. Exp. Biol. 203, 2957-2966.

Pillans, R.D., Good, J.P., Anderson, W.G., Hazon, N., Franklin, C.E., 2005. Freshwater to seawater acclimation of juvenile bull sharks (Carcharhinus leucas): plasma osmolytes and $\mathrm{Na}^{+} / \mathrm{K}^{+}$-ATPase activity in gill, rectal gland, kidney and intestine. J. Comp. Physiol. B 175, $37-44$.

Prunet, P., Sturm, A., Milla, S., 2006. Multiple corticosteroid receptors in fish: from old ideas to new concepts. Gen. Comp. Endocrinol. (this volume).

Rabkin, R., Schaefer, F., 2004. New concepts: growth hormone, insulinlike growth factor-I and the kidney [Review]. Growth Horm. IGF Res. $14,270-276$.

Sakamoto, T., McCormick, S.D., 2006. Prolactin and growth hormone in fish osmoregulation. Gen. Comp. Endocrinol. (this volume).

Skadhauge, E., 1981. Osmoregulation in Birds. Springer, Berlin.

Shane, M.A., Nofzinger, C., Blazer-Yost, B.L., 2006. Hormonal regulation of the epithelial $\mathrm{Na}^{+}$channel: from amphibians to mammals. Gen. Comp. Endocrinol. (this volume).

Takei, Y., 2001. Does the natriuretic peptide system exist throughout the animal and plant kingdom? Comp. Biochem. Physiol. B 129, 559-573.

Takei, Y., Hasegawa, Y., Watanabe, T.X., Nakajima, K., Hazon, N., 1993. A novel angiotensin I isolated from an elasmobranch fish. J. Endocrinol. 139, 281-285.

Toop, T., Donald, J.A., 2004. Comparative aspects of natriuretic peptide physiology in non-mammalian vertebrates: a review. J. Comp. Physiol. B 174, 189-204.

Tsukada, T., Takei, Y., 2006. Integrative approach to osmoregulatory action of atrial natriuretic peptide in seawater eels. Gen. Comp. Endocrinol. (this volume).

Uchiyama, M., Konnu, N., 2006. Osmoregulation in anuran amphibians: hormonal regulation of ion and water transport. Gen. Comp. Endocrinol. (this volume).
410 